\title{
Pest Complex of Lemon CV. Assam Lemon (Citrus limon L. Burm) in Terai Region of West Bengal, India
}

\author{
Tanuj Debbarma* and T. K. Hath \\ Department of Agricultural Entomology, Uttar Banga Krishi Vishwavidyalaya, \\ UBKV, Pundibari, West Bengal, India \\ *Corresponding author
}

Keywords

orange (Citrus sinensis), lemon (Citrus limon), grapefruit (Citrus paradisi)

\section{Article Info}

\section{Accepted:}

18 March 2021

Available Online: 10 April 2021
In a two-year study conducted in 2013 and 2014 in terai zone of West Bengal, India, 18 insect pests and 2 mite species were recorded from the lemon tree of CV. Assam Lemon (Citrus limon L. Burm). Among the insect pests, six species belonged to order Lepidoptera, seven species to Hemiptera while five species were from Coleoptera. The studies revealed that major insect pests of the region were citrus leaf miner (Phyllocnistis citrella Stainton), citrus psylla, (Diaphorina citri Kuwayama) and lemon butterfly (Papilio demoleus Linnaeus). Other important insect pests include leaf mining flea beetles (Podagrigomela nigripes Medvedev), leaf roller (Psorosticha zizyphi Stainton), citrus aphid (Toxoptera citricida Kirkaldy), citrus whitefly (Dialeurodes citri Ashmead), citrus blackfly (Aleurocanthus woglumi Ashby) and ash weevils (Lepropus lateralis F. and Deiradolcus sp.). The two mite species, citrus red mite (Panonychus citri McGregor) and citrus rust mite (Phyllocoptruta oleivora Ashmead) belonged to Tetranychidae Eriophyidae respectively. Besides, as many as 15 different species of natural enemies consisting of 7 species of coccinellid predators, 3 species of hymenopteran parasitoids, 2 species of spiders, one species each of lace wing and unidentified hoverfly were identified from the citrus plants. This was the first ever study in the region.

\section{Introduction}

Amongst fruit crops, citrus (Citrus spp.; Rutaceae) occupies a chief place and owing to its wide adaptability to various climatic conditions they are grown in different parts of the world including tropical, subtropical and temperate regions. The most popular citrus comprises orange (Citrus sinensis), lemon
(Citrus limon), grapefruit (Citrus paradisi), lime (Citrus aurantifolia) and mandarin (Citrus reticulata). India ranks fifth in the world in area and production of citrus and lime and lemon are considered to be the most important fruits under citrus in the country (Anonymous, 2018). In India, Lime and Lemons are the most important citrus crops after oranges and mosambia (Citrus limetta 
Risso). Among the various reasons limiting the production of citrus in India, prevalence of pests and diseases is the major one. As many as 823 insect and mite pests inflict damage to citrus species throughout the world (Ebeling, 1959) of which 250 insects were reported to be occurring in India (Butani, 1979). However, Pruthi and Mani (1945) earlier reported that citrus crops were infested by 165 insect pests in India causing 30\% yield loss. From Darjeeling district (in West Bengal), which is an important orange growing area of the North-East India, Nath (1969) for the first time documented 82 species occurring on citrus, of which 37 species were new record. Later studies indicated that citrus crops are ravaged by varying numbers of insect pests and mites during different years. Patel et al., (1970) reported eleven species of insect pests, being serious in Gujarat, which included citrus leaf miner, citrus butterfly, citrus psylla, citrus leaf roller, citrus whitefly, citrus fruit sucking moth, mealy bug, citrus aphids, red and white ants. Nair (1986) listed about 179 different species of insects and mites. Reddy et al., (1989) recorded about 55 species of insect and mite in Southern Andhra Pradesh, where citrus leaf miner was noted to be an important pest in nursery as well as main field. Donkersley (2018) reported that lime trees were infested by 15 different insects, mites and nematode.

Although numerous pests assault citrus plants, the citrus butterfly (Papilio demoleus Linnaeus), citrus leaf miner (Phyllocnistis citrella Stainton), leaf folder (Psorosticha ziziphi Stainton), ash weevil (Myllocerus discolor Fab.), psylla (Diaphorina citri Kuwayama) and rust mite (Phyllocoptes oleivorus Ashmead) are considered to be the most notorious pests and leaf miner and citrus butterfly occur regularly in nurseries, young plantation and on new flushes of grown up trees. Barua and Bharadwaj (2017) described Assam Lemon, locally known as 'Kazi Nemu', to be the most common citrus fruit in
Assam. Terai region of West Bengal which is adjacent to Assam is a vast area, suitable for cultivation of lime and lemon due to prevalence of conducive climate and soil and people in this large area grow lime/lemon as a kitchen garden plant for meeting their domestic need as well as for commercial purposes. In West Bengal, citrus is cultivated in an area of 11.71 thousand hectare with a production of 109.40 thousand tons (Anonymous, 2013). Though scanty references on the pests of oranges of Darjeeling district are available, practically no information about the pest complex of any of the citrus crop in the terai zone of West Bengal, are available. Accordingly the studies were undertaken.

\section{Materials and Methods}

The experiment was conducted in the existing lemon orchard of the University located at Pundibari, Cooch Behar, West Bengal, India and lies between $25^{\circ} 57^{\prime} \mathrm{N}$ to $27^{\circ} \mathrm{N}$ latitude and $88^{\circ} 25^{\prime} \mathrm{E}$ to $58^{\circ} 54^{\prime} \mathrm{E}$ longitude in two consecutive years viz. 2013 and 2014. Four plants with equal vigour were selected at random in the orchard. The tree canopy was divided into three segments, viz. top, middle and lower and from each segment, three branches were selected and tagged whereas from each branch, four shoots were randomly considered for recording the insect pests. The eggs, immature stages/ larvae and adults were collected and identified under stereomicroscope in the laboratory and assistance of the taxonomists was taken to identify the insect pests. Identification keys of Martin (1987; 1996; 2000) and Martin et al., (2000) were consulted for identification of the whiteflies and blackflies. Counting of the natural enemies was also done from the selected branches/ shoots from each canopy of the selected plants. Infested leaves (by insect pests) were plucked and kept back in polythene bags and non-absorbent cotton was 
used to plug for aeration of inhabiting natural enemies. The collected leaves were examined twice a week and two weeks later, the samples were meticulously studied under microscope to record the natural enemy. Data on the insect pests were collected at weekly intervals from the tagged plants/ branches/ shoots during three major flush periods a year, i.e., in the months of February-March, May-June and October-November in each year of studies.

\section{Results and Discussion}

\section{Pest complex of Assam Lemon}

The results presented in table no.1 illustrate that during the different seasons of the year a total of 18 different species of insects and 2 mite species occurred on Assam Lemon plants. Insect species belonged to fourteen families under three different orders namely, Lepidoptera, Coleoptera and Hemiptera. Among these, Lepidoptera constituted six species, Coleoptera five species and Hemiptera seven species of insects.

Among Lepidoptera, two species of lemon butterfly under Papilionidae, Papilio demoleus Linnaeus and Papilio polytes Linnaeus; one species of citrus leaf miner, Phyllocnistis citrella Stainton under Phyllocnistidae; one species of leaf roller, Psorosticha zizyphi Stainton under Depressariidae; one species of Indian Lime Blue, Chilades lajus Stoll under Lycaenidae and one species of bark-eating caterpillar, Inderbela sp under Cossidae were recorded.

The Hemipteran insect pests of lemon recorded in this area comprised one species of citrus psylla, Diaphorina citri Kuwayama under Liviidae; one species of citrus aphid, Toxoptera citricida Kirkaldy under Aphididae; one species of whitefly, Dialeurodes citri Ashmead and one species of citrus blackfly, Aleurocanthus woglumi Ashby under
Aleyrodidae; two species scale insects, Aonidiella sp. and Coccus hesperidum Linnaeus under Diaspididae and Coccidae, respectively; one species of mealy bug, Planococcus citri Risso under Pseudococcidae family.

Among Coleoptera, one species of leafmining beetle, Podagricomela nigripes Medvedev under Chrysomelidae; two species of ash weevils, Lepropus lateralis Fabricius and Deiradolcus sp. under Curculionidae; one species of citrus tree borer, Oemona hirta Fabricius and one species of trunk borer, Anoplophora versteegi Ritsema under Cerambycidae were recorded.

Besides the above, two mite species namely, citrus red mite, Panonychus citri McGregor under Tetranychidae and citrus rust mite, Phyllocoptruta oleivora Ashmead under Eriophyidae family were recorded from the lemon tree.

In the present study, a total of 20 different insects (18 species) and mites (2 species) species were recorded in Assam Lemon from terai region of West Bengal. Various workers reported varied number of insect pests, mites and nematodes from different parts of the country and abroad from citrus trees viz. orange, lime and lemon. Nath (1969) from Darjeeling District of West Bengal (NorthEast India) reported a total of 82 species of insects from orange trees. Patel et al., (1970) recorded 11 species of insect pests on citrus trees in Gujarat region, which included citrus leaf miner, lemon butterfly, citrus psylla, citrus leaf roller, citrus whitefly, mealy bug, citrus mites and fruit sucking moth and two ant species. Koli et al., (1981) under Maharashtra condition recorded 24 insect and mite species on sweet orange trees and they observed citrus psylla as an important pest. From southern Andhra Pradesh, Reddy et al., (1989) recorded 55 species of insects and 
mites on citrus plants and according to them citrus leaf miner was the most important pest in the nursery and main field as well. Hussain et al., (2017) from Keren, Eritrea recorded the infestation of five insect pests which included woolly whitefly (Aleurothrixus sp.), cottony cushion scale (Icerya purchasi), citrus leaf miner (Phyllocnistis sp.), diaspine black scale (Parlatoria sp.) and brown scale (Coccus sp.). Donkersly et al., (2018) from Brazil reported that 15 different insects, mites and nematode infesting lime trees and citrus psylla, aphids and thrips were the important ones.

Thus the results of the present study are in conformity with the above works. The number and species of insect pests varied from region to region. The occurrence of insect pests depends upon the type of plants, geographical locations, climatic conditions and seasons.

Difference in the number and species of insect pests may be due to variation in the geographical area, climatic conditions and the type of citrus species studied.

\section{Natural enemy complex of Assam Lemon}

The recorded natural enemy complex in the lemon plants included Coccinellid predators, Spiders, Hymenopteran parasitoids, Chrysopid predators and Hoverflies. The Coccinellid predators comprised seven different species viz. Menochilus sexmaculatus Fabricius, Coccinella septempunctata Linnaeus, Cryptogonus bimaculatus Kapur, Cryptogonus quadriguttatus Weise, Jauravia pallidula Motschulsky, Micraspis discolor Fabricius and Chilocorus sp.

The Hymenopteran parasitoids consisted of Aphytis sp. and Encarsia sp. under the family Aphelinidae and Pristomerus sp. under the family Ichneumonidae. Apart from the Coccinellids and hymenopteran parasitoids, two species of spiders (Phintella vittata and Hibana sp.), chrysopids (Chrysopa sp.) and hoverflies were also recorded during the period of investigation.

In the present study, a total of 15 different species of natural enemies (table no. 2) were recorded from lemon trees which comprised 7 species of Coccinellid predators, 3 species of Hymenopteran parasitoids, 2 species of spiders, one species of lace wing and one unidentified species of hoverfly.

In citrus ecosystem, natural enemies predominate and various studies revealed that natural enemies operate their activities during different seasons and they also play an important role in keeping the pest population at a lower level.

Narayan et al., (1957) reported that 3 larval parasitoids namely, Amatellon sp, Tetrastichus sp and Elasmus sp caused $33 \%$ parasitisation of citrus leaf miner whereas Ding et al., (1989) observed 67.6\% parasitisation of citrus leaf miner by Tetrastichus phyllocnistoides. Schauff et al., (1998) mentioned that more than 80 species of Chalcidoid parasitoids attack citrus leaf miner worldwide. Atwal (1964) and Ramzan and Singh (1979) reported that the pupae of Papilio demoleus were parasitized by Pteromalus puparum. Singh (1967) reported two hymenopteran parasitoids namely, Charcops sp. and Brachymeria sp. from the larvae of Papilio demoleus while Krishnamoorthy and Singh (1986) recorded two egg parasitoids namely, Trichogramma chilonis and Telenomus sp. on the larvae of Papilio demoleus and $P$. polytes and they observed that Trichogramma chilonis had high level of parasitisation (75\%). Jalali and Singh (1990) recorded three parasitoids namely, Ooencyrtus papilionis apart from Telenomus sp and Trichogramma sp. from the eggs of $P$. demoleus. 
Table.1 Pest complex of Assam Lemon (Citrus limon L. Burm) in the terai region of West Bengal

\begin{tabular}{|c|c|c|c|c|}
\hline $\begin{array}{l}\text { Sl. } \\
\text { No. }\end{array}$ & $\begin{array}{c}\text { Common } \\
\text { Name }\end{array}$ & Scientific Name & Family & Order \\
\hline 1 & $\begin{array}{l}\text { Citrus leaf } \\
\text { miner }\end{array}$ & $\begin{array}{l}\text { Phyllocnistis citrella } \\
\text { Stainton }\end{array}$ & Phyllocnistidae & \multirow{6}{*}{ Lepidoptera } \\
\hline 2 & \multirow{2}{*}{$\begin{array}{l}\text { Lemon } \\
\text { butterfly }\end{array}$} & Papilio demoleus Linnaeus & \multirow{2}{*}{ Papilionidae } & \\
\hline 3 & & Papilio polytes Linnaeus & & \\
\hline 4 & Leaf roller & Psorosticha zizyphi Stainton & Depressariidae & \\
\hline 5 & $\begin{array}{l}\text { Bark eating } \\
\text { caterpillar }\end{array}$ & Inderbela $\mathrm{sp}$. & Cossidae & \\
\hline 6 & $\begin{array}{l}\text { Indian Lime } \\
\text { Blue }\end{array}$ & Chilades lajus Stoll & Lycaenidae & \\
\hline 7 & Citrus psylla & Diaphorina citri Kuwayama & Liviidae & \multirow{7}{*}{ Hemiptera } \\
\hline 8 & Citrus aphid & Toxoptera citricida Kirkaldy & Aphididae & \\
\hline 9 & Whitefly & Dialeurodes citri Ashmead & Aleyrodidae & \\
\hline 10 & Blackfly & $\begin{array}{l}\text { Aleurocanthus woglumi } \\
\text { Ashby }\end{array}$ & Aleyrodidae & \\
\hline 11 & \multirow[b]{2}{*}{ Scale insects } & Aonidiella sp. & Diaspididae & \\
\hline 12 & & $\begin{array}{c}\text { Coccus hesperidum } \\
\text { Linnaeus }\end{array}$ & Coccidae & \\
\hline 13 & Mealybug & Planococcus citri Risso & Pseudococcidae & \\
\hline 14 & $\begin{array}{l}\text { Citrus leaf } \\
\text { mining flea } \\
\text { beetle }\end{array}$ & $\begin{array}{c}\text { Podagricomela nigripes } \\
\text { Medvedev }\end{array}$ & Chrysomelidae & \multirow{5}{*}{ Coleoptera } \\
\hline 15 & Ash weevil & Lepropus lateralis Fabricius & Curculionidae & \\
\hline 16 & Asn weevil & Deiradolcus sp. & Curcuinonidae & \\
\hline 17 & $\begin{array}{l}\text { Citrus tree } \\
\text { borer }\end{array}$ & Oemona hirta Fabricius & \multirow{2}{*}{ Cerambycidae } & \\
\hline 18 & Trunk borer & $\begin{array}{c}\text { Anoplophora versteegi } \\
\text { Ritsema }\end{array}$ & & \\
\hline 19 & Citrus red mites & Panonychus citri McGregor & Tetranychidae & Trombidiformes \\
\hline 20 & $\begin{array}{l}\text { Citrus rust } \\
\text { mites }\end{array}$ & $\begin{array}{l}\text { Phyllocoptruta oleivora } \\
\text { Ashmead }\end{array}$ & Eriophyidae & Prostigmata \\
\hline
\end{tabular}


Table.2 Natural enemy complex of Assam Lemon (Citrus limon L. Burm) in the terai region of West Bengal

\begin{tabular}{|c|c|c|c|c|}
\hline $\begin{array}{l}\text { Sl. } \\
\text { No. }\end{array}$ & Common Name & Scientific Name & Family & Order \\
\hline 1 & \multirow{7}{*}{$\begin{array}{l}\text { Coccinellid } \\
\text { predators }\end{array}$} & $\begin{array}{l}\text { Menochilus sexmaculatus } \\
\text { Fabricius }\end{array}$ & \multirow{7}{*}{ Coccinellidae } & \multirow{7}{*}{ Coleoptera } \\
\hline 2 & & $\begin{array}{l}\text { Coccinella septempunctata } \\
\text { Linnaeus }\end{array}$ & & \\
\hline 3 & & $\begin{array}{l}\text { Cryptogonus bimaculatus } \\
\text { Kapur }\end{array}$ & & \\
\hline 4 & & $\begin{array}{c}\text { Cryptogonus quadriguttatus } \\
\text { Weise }\end{array}$ & & \\
\hline 5 & & $\begin{array}{l}\text { Jauravia pallidula } \\
\text { Motschulsky }\end{array}$ & & \\
\hline 6 & & Micraspis discolor Fabricius & & \\
\hline 7 & & Chilocorus $\mathrm{sp}$ & & \\
\hline 8 & \multirow{3}{*}{ Spiders } & Phintella vittata Koch & Salticidae & \multirow{3}{*}{ Araneae } \\
\hline 9 & & Marpissa sp. & & \\
\hline 10 & & Hibana sp. & Anyphaenidae & \\
\hline 11 & \multirow{3}{*}{$\begin{array}{l}\text { Hymenopteran } \\
\text { parasitoids }\end{array}$} & Aphytis sp. & Anhelinidae & \multirow{3}{*}{ Hymenoptera } \\
\hline 12 & & Encarsia sp. & & \\
\hline 13 & & Pristomerus sp. & $\begin{array}{c}\text { Ichneumonida } \\
\mathrm{e}\end{array}$ & \\
\hline 14 & Green lacewing & Chrysopa sp. & Chrysopidae & Neuroptera \\
\hline 15 & Hoverfly & & Syrphidae & Diptera \\
\hline
\end{tabular}

Bindra (1970) and Nair (1975) reported five species of coccinellid beetles namely, Coccinella septumpunctata L, C. rependa, Chilomenes sexmaculata F., Chilocorus nigritus $\mathrm{F}$. and Brumus suturalis $F$. a syrphid fly and a Chrysopa sp. preying on the nymphs of citrus psylla. Rao (2004) recorded four coccinellids namely, Chilonemus sexmaculata F., Coccinella septumpunctata L., Brumus suturalis F. and Chilocorus nigritus F.; one lacewing, Chrysopa sp. and one praying mantis predating on citrus psylla. Ramya et al., (2016) recorded 12 species of coccinellids from Assam of which Coccinella transversalis and Harmonia dimidita were the most abundant. Gurung et al., (2019) recorded 6 species of Coccinellid beetles from citrus orchard of West Bengal where Cryptogonus quadriguttatus Weise was the most abundant. Sanda (1991) observed Marpissa tigrina as an efficient spider predator of citrus psylla while Van den Berg et al., (1991) reported Hibana velox preying on the nymphs of citrus psylla. Sarada et al., (2014) observed that ants, spiders, small parasitic wasps and lace wings were acting as predators of citrus leaf miner and among these, lace wings caused upto 90\% mortality of larvae and pupae. Aruna et al., (2017) also recorded that spider activity was maximum during April and lower during November and December.

Thus the results of the present study corroborate the works as elaborated above. Various workers studied the diversity of natural enemies and their hosts, rate of 
parasitisation and stage of the hosts where the parasitisation or predation occurred. Since the above consideration was beyond the scope of the present study, the result has been presented only on the diversity of the natural enemies as well as the host wherever the parasitoids could be identified from the specific host.

It may thus be concluded that in terai zone of West Bengal, India, lemon plants were infested by 18 species of insects and 2 species of mites. On the other hand 15 different species of insect predators and parasitoids and spiders occurred as natural enemies. This was the first ever report from the region.

\section{Acknowledgements}

The authors thankfully acknowledge the assistance rendered by Dr. K. D. Prathapan, Dr. J. Poorani and Dr. P. R. Sashank for identification of the specimens of citrus leaf mining flea beetle (Podagricomela nigripes Medvedev), ash weevils (Lepropus lateralis Fabricius and Deiradolcus sp.) and indian lime blue (Chilades lajus Stoll), respectively.

\section{References}

Anonymous (2013). Area Production Statistics. National Horticulture Board. http://nhb.gov.in. (Accessed on 10.05.2018).

Anonymous (2018). Area Production Statistics. National Horticulture Board. http://nhb.gov.in. (Accessed on 05.02.2019).

Aruna, J.; Jagginavar, S. B.; Karabhantanal, S. S. and Huilgol, S. N. (2017). Seasonal incidence of citrus blackfly, Aleurocanthus woglumi Ashby and its natural enemies on Acid Lime. Journal of Experimental Zoology, India, 20(1): $1519-1523$.

Atwal, A. S. (1964). Insect pests of citrus in the Punjab - Biology and control of
Citrus Caterpillar. Papilio demoleus L. (Lepidoptera: Papilionidae). Punjab Horticultural Journal, 4: 40-44.

Barua, B. C. and Bharadwaj, S. (2017). Assam Lemon - A Prospective NPD Initiative Aimed at Global Market Positioning. International Journal of Research, 4 (14).

Bindra, O. S. (1970). Citrus decline in India causes and control. Joint Publication of P.A.U. and OSU/USAIO, Ludhiana, Punjab. pp. 64-78.

Butani, D. K. (1979). Insect pests of citrus and their control. Pesticides, 13 (4): 15-21.

Ding, Y. M.; Li, M. and Huang, M. D. (1989). Studies on biology of two species of parasitoids Tetrastichus phyllocnistoides and Cirrospilus quadristriatus and their parasitization on the citrus leaf miner, Phyllocnistis citrella Stainton. In: Studies on the Integrated Management of Citrus Insect Pests (in Chinese, English summary). Ed. by Huang, M. D. Beijing: Academic Book and Periodical Press. 1989; 1063-113.

Donkersley, P.; Silva, F. W. S.; Carvalho, C. M.; Al-Sadi, A. M. and Elliot, S. L. (2018). Biological, environmental and socioeconomic threats to citrus lime production. Journal of Plant Diseases and Protection, 125: 339-356.

Ebeling, W. (1959). Subtropical fruit pests. University of California Press, California, USA. 436p.

Gurung, B.; Ponnusamy, N. and Pal, S. (2019). Species diversity of predaceous coccinellids in different crop ecosystems under the hilly and terai region of West Bengal (India). Ecology, Environment and Conservation, 25 (2): 152-158.

Hussain M Abid, Tufail Ahmad, Mical Tekeste, Nahom Teklemariam, Nardos Abraham and Niyat Mehari (2017). A case study of insect pest complex of 
citrus and their management at Keren, Eritrea, and a note on their natural enemies. Journal of Entomology and Zoology Studies. 5(3): 1226-1230.

Jalali, S. K. and Singh, S. P. (1990). A new record of Ooencyrtus papilionis (Hymenoptera: Encyrtidae) on the eggs of Papilio demoleus (Linn.) from India. Journal of Biological Control, 4 (1): 59-60.

Koli, S. Z.; Makar, P. V. and Chaudhary, K. G. (1981). Seasonal abundance of citrus pests and their control. Indian Journal of Entomology, 42: 183-187.

Krishnamoorthy, A. and Singh, S. P. (1986). Record of the egg parasite, Trichogramma chilonis on Papilio spp. in citrus. Current Science, 55 (9): 461.

Marker, P. V.; Chandari, K. G. and Shewale, B. S. (1984). Economics and efficacy of different methods to control citrus leaf miner (Phyllocnistis citrella Stainton). Pestology, 8 (3): 15-16.

Martin, J. H (1987). An identification guide to common whitefly pest species of the world (Homoptera, Aleyrodidae). Tropical Pest Management. 33(4): 298-322.

Martin, J. H. (1996). Neotropical whiteflies of the subfamily Aleurodicinae established in the western Palaearctic (Homoptera: Aleyrodidae). Journal of Natural History. 30: 1849-1859.

Martin, J. H. (2000). The occurrence of Dialeurodes citrifolii and Aleurochiton pseudoplatani

(Hemiptera: Aleyrodidae) in Lebanon-important new records in the EuropeMediterranean Region. Bulletin of Entomological Research. 90: 527-528.

Martin, J. H., Mifsud D, Rapisarda C. (2000). The whiteflies (Hemiptera: Aleyrodidae) of Europe and the Mediterranean Basin. Bulletin of Entomological Research. 90: 407-448.

Nair, M. R. G. K. (1975). Insects and mites of crops in India. Indian Council of Agricultural Research, New Delhi, pp. 185.

Nair, M. R. G. K. (1986). Insects and mites of crops in India. Indian Council of Agricultural Research, New Delhi (India).

Narayan, E. S.; Subba Rao, B. R. and Kaur, R. B. (1957). Notes on the biology of the parasites of the leaf miner of citrus plants. Proceedings of $44^{\text {th }}$ Indian Science Congress III: 396-397.

Nath, D. K. (1969). Studies on the citrus pests of West Bengal. A Ph.D. thesis submitted to the University of Calcutta, West Bengal (India).

Patel, H. K.; Patel, V. C. and Patel, J. R. (1970). "Catalogue of crop pests of Gujarat State". Dept. of Agric., Gujarat State. Technical Bulletin, 6: 34-35.

Pruthi, H. S. and Mani, M. S. (1945). Our knowledge of the insects and mite pests of citrus in India and their control. Indian Council of Agricultural Research, Scientific Monograph, 16: 142.

Ramya, H. R. and Thangjam, R. (2016). Predatory coccinellids of insect pests of Assam lemon (Citrus limon L. Burmf) in Jorhat district of Assam. Journal of Biological control, 30 (2): 121-123.

Ramzan, M and Singh, D. (1979). Record of Pteromalus puparum Linn. (Hymenoptera: Pteromalidae) from pupae of lemon butterfly Papilio demoleus Linn. at Ludhiana. Journal of Bombay Natural History Society, 75 (3): 931-932.

Rao, K. P. (2004). Seasonal abundance and management of major citrus pests of South Zone. M.Sc. (Ag.) thesis submitted to the Andhra Pradesh Agricultural University. 194 pages.

Reddy, R. K, Savithri, P. and Rao, K. P. (1989). Pest complex of citrus in 
Rayalaseema region. The Andhra Agricultural Journal, 36 (1): 68-71.

Sanda, G. L. (1991). Mode of hunting and functional response of the spider Marpissa tigrina Ticader to the density of its prey Diaphorina citri. Entomon, 16: 279-282.

Sarada, G.; Gopal, K.; Nagalakshmi, T.; Venkataramana, $\quad$ K. $\quad T$.; Mukundalakshmi, L.; Gouri Shankar, T. and Gopi, V. (2014). Management of Citrus psylla (Diaphorina citri Kuwayama) Using Bio-Rational Insecticides. Research and Reviews: Journal of Ecology and Environmental Sciences. e-ISSN: 2347-7830/p-ISSN: 2347-7822.

Schauff, M. E.; Lasalle, J. and Wijesekara, G.
A. (1998). The genera of Chalcidoid parasitoids (Hymnoptera: Chalcidoidea) of citrus leafminer, Phyllocnistis citrella Stainton (Lepidoptera: Gracillaridae). Journal of National History, 32: 1001-1056.

Singh, Y. N. (1967). New record of hymenopterous parasites of Papilio demoleus L. serious pest of citrus sp. Bulletin of Entomology, 8: 163.

Van den Berg, M. A.; Deacon, V. E.; Steenekamp, P. J. (1991). Dispersal within and between citrus orchards and native hosts, and nymphal mortality of citrus psylla, Trioza erytreae (Hemiptera: Triozidae). Agriculture, Ecosystems and Environment, 35: 297309.

\section{How to cite this article:}

Tanuj Debbarma and Hath, T. K. 2021. Pest Complex of Lemon CV. Assam Lemon (Citrus limon L. Burm) in Terai Region of West Bengal, India. Int.J.Curr.Microbiol.App.Sci. 10(04): 736-744. doi: https://doi.org/10.20546/ijcmas.2021.1004.075 